\title{
EFFECT OF DIFFERENT PLANTING LOCATIONS IN EGYPT ON SALVIA FRUTICOSA MILL. PLANTS
}

\author{
Abd El-Wahab, Mohamed A., Wael I.M. Toaima and Emad S. \\ Hamed* \\ Department of Medicinal and Aromatic Plants, Ecology and Dry \\ Lands Agriculture Division, Desert Research Center, 11753 El- \\ Matareya, Cairo, Egypt \\ *E-mail: dr.emad128@yahoo.com
}

\begin{abstract}
$\mathrm{T}$ his work was carried out during the two successive seasons of 2012/2013 and 2013/2014 to study the effect of different planting locations on three-lobed sage (Salvia fruticosa Mill.) plants. The experiment was conducted at three different locations in newly reclaimed lands as follows: El-Qantara Sharq (North Sinai Governorate), El-Maghara Village (North Sinai Governorate) and Siwa Oasis (Matrouh Governorate). The results indicated that all herb quantity and quality parameters were varied according to location and harvesting time. The best location for cultivation of this plant was El-Maghara location, which recorded the highest herb quantity parameters (number of cuts per season, fresh and dry weights of herb per plant or per feddan) as well as the highest herb quality parameters (essential oil yield per plant or per feddan with a suitable content of 1,8 cineole compound as the main chemical constituent of the oil), followed by El-Qantara Sharq location and then Siwa Oasis location.
\end{abstract}

Keywords: three-lobed sage, growth, essential oil, North Sinai, Siwa Oasis

Evaluation of the productivity and quality of medicinal and aromatic plants at variable ecosystem locations in Egypt is considered a main target today, especially under current global climate changes problem and its negative impacts on agriculture (Abd El-Wahab, 2013; Amedie, 2013 and FAO, 2015).

Salvia fruticosa Mill. (syn. Salvia triloba L.f.) or three-lobed sage (syn. Greek sage, Turkish sage) is an interesting medicinal and aromatic shrub belongs to family Lamiaceae, clearly differentiated from Salvia officinalis because of its trifoliate leaves. The plant is endemic to the Eastern Mediterranean basin and its total native range extends from Cyrenaica, Sicily and Southern Italy, through the southern part of the Balkan Peninsula to West Syria. On the world market, the main suppliers of three-lobed sage are 
Greece, Turkey, Albania, Cyprus and Crete, where most of production is collected from wild populations (Putievsky et al., 1986; Rivera et al., 1994; Kintzios, 2003 and International Trade Center Report, September and December 2015).

In the Middle East, the plant is known as mariamia and it is used widely in folk medicine as a medicinal tea to improve digestion and relieve cold symptoms, a cure for liver diseases, to regulate menstruation, to treat mouth sores, to accelerate wound healing and to relive recall pains. The essential oil isolated from its leaves is antifungal, antibacterial and is mainly composed of 1,8-cineole compound. Considering the importance of this wild plant, some countries in the Middle East; such as Lebanon, regulated wild collection and export Salvia fruticosa by ministerial decision 179/1, March 2012. Also, in Israel the plant was marked as a protected plant due to excessive gathering from the wild by healers and users (UNDP, GEF and LARI, 2013; Yaniv and Dudai, 2014 and European Medicines Agency, 2015).

In Egypt, three-lobed sage plants are currently cultivated at small scale in El-Sheikh Zowayed and Rafah locations (North Sinai Governorate) and there is no literature on the effect of different planting locations on quantity and quality of the herb and its essential oil. The government's policy is concerned to reclaim new lands and medicinal and aromatic plants are very suitable crops for these lands. So, the aim of this work was to evaluate the production of Salvia fruticosa under different locations to introduce a database of information for herbs growers and pharmaceutical industry in the country.

\section{MATERIALS AND METHODS}

This experiment was carried out during the two successive seasons of $2012 / 2013$ and 2013/2014 at three different locations in newly reclaimed lands as follows:

1- North Sinai Governorate (El-Qantara Sharq).

2- North Sinai Governorate (El-Maghara Village).

3- Matrouh Governorate (Siwa Oasis - Khamisa Village).

Seedlings of Salvia fruticosa were kindly obtained from El-Sheikh Zowayed Experimental Station, Desert Research Center, North Sinai Governorate. The seedlings were transplanted successfully in the open field at the different locations on March 2012 and 2013 for the first and second seasons, respectively. Planting was carried out under drip irrigation system in rows $75 \mathrm{~cm}$ apart and $50 \mathrm{~cm}$ between hills as one plant/hill. In all locations, compost manure was added during soil preparation at a rate of 10 $\mathrm{m}^{3} /$ feddan. The chemical fertilizers were added as the recommended fertilization dose for sage plants in sandy soil (Abd El-Azim, 2003). All 
agricultural practices were done according to the recommendations of the Egyptian Ministry of Agriculture.

The plants were harvested three times per season, i.e. on July, November and March at El-Qantara Sharq and El-Maghara locations, while at Siwa Oasis location two cuts were taken per season, i.e. on November and March. Harvesting was done by cutting the vegetative parts of plants $15 \mathrm{~cm}$ above the soil surface leaving two branches for regrowth.

The experimental layout was a complete randomized design (3 treatments) with three replicates. L.S.D. test at 0.05 was used to compare the average means of treatments, according to Snedecor and Cochran (1982).

The following data were recorded:

1. Geographical Information about the Different Locations

\subsection{GPS data}

The latitude and longitude data for the different locations were recorded and are presented in table (1).

\subsection{Soil analyses}

At the beginning of the experiment, soil samples were collected from the soil surface layer $(30 \mathrm{~cm})$ to determine the mechanical and chemical soil properties for the different locations. All soil samples were analyzed at the laboratories of Desert Research Center and Soils, Water and Environment Research Institute. The results are shown in tables (2 and 3).

\subsection{Irrigation water analyses}

Irrigation water samples were analyzed at the laboratories of Desert Research Center and Soils, Water and Environment Research Institute. The results are illustrated in table (4).

\subsection{Meteorological data}

The meteorological data for the different locations during the seasons of 2012/2013 and 2013/2014 are shown in tables (5, 6 and 7).

Table (1). The GPS data for the different locations.

\begin{tabular}{lcc}
\hline Locations & Latitude $(\mathbf{N})$ & Longitude $(\mathbf{E})$ \\
\hline El-Qantara Sharq & 30.75 & 32.50 \\
El-Maghara & 30.71 & 33.33 \\
Siwa Oasis & 29.21 & 25.40 \\
\hline
\end{tabular}

Table (2). The mechanical analysis of the soil at the experimental sites.

\begin{tabular}{lcccc}
\hline Locations & Sand (\%) & Silt $(\%)$ & Clay (\%) & Soil texture \\
\hline El-Qantara Sharq & 91.80 & 5.80 & 2.40 & Sandy \\
El-Maghara & 95.00 & 4.00 & 1.00 & Sandy \\
Siwa Oasis & 92.91 & 5.21 & 1.88 & Sandy \\
\hline
\end{tabular}


Table (3). The chemical analysis of the soil at the experimental sites.

\begin{tabular}{|c|c|c|c|c|c|c|c|c|c|c|c|}
\hline \multirow[t]{2}{*}{ Locations } & \multirow[t]{2}{*}{ pH } & \multirow{2}{*}{$\begin{array}{c}\text { E.C. } \\
\text { (ds/m) } \\
\end{array}$} & \multirow{2}{*}{$\begin{array}{l}\text { O.M. } \\
(\%) \\
\end{array}$} & \multicolumn{4}{|c|}{$\begin{array}{c}\text { Soluble anions } \\
(\mathrm{meq} / \mathrm{l})\end{array}$} & \multicolumn{4}{|c|}{$\begin{array}{c}\text { Soluble cations } \\
(\mathrm{meq} / \mathrm{l})\end{array}$} \\
\hline & & & & $\mathrm{CO}_{3}^{--}$ & $\mathrm{HCO}_{3}^{-}$ & $\mathrm{Cl}^{-}$ & $\mathrm{SO}_{4}{ }^{--}$ & $\mathrm{Ca}^{++}$ & $\mathrm{Mg}^{++}$ & $\mathrm{Na}^{+}$ & $\mathbf{K}^{+}$ \\
\hline El-Qantara Sharq & 8.2 & 0.9 & 0.2 & - & 0.6 & 4.9 & 2.0 & 2.1 & 0.9 & 3.8 & 0.7 \\
\hline El-Maghara & 7.9 & 2.8 & 0.5 & - & 1.0 & 20.0 & 7.0 & 6.0 & 8.0 & 12.6 & 1.4 \\
\hline Siwa Oasis & 7.5 & 4.1 & 0.5 & - & 3.6 & 31.3 & 6.1 & 8.6 & 7.5 & 0.2 & 24.7 \\
\hline
\end{tabular}

Table (4). The chemical analysis of irrigation water at the experimental sites.

\begin{tabular}{lcccccccccc}
\hline Locations & $\mathbf{p H}$ & $\mathbf{E . C}$ & \multicolumn{3}{c}{$\begin{array}{c}\text { Soluble anions } \\
(\mathbf{m e q} / \mathbf{l})\end{array}$} & \multicolumn{4}{c}{$\begin{array}{c}\text { Soluble cations } \\
(\mathbf{m e q} / \mathbf{l})\end{array}$} \\
\cline { 2 - 11 } & \multicolumn{3}{c}{$\mathbf{p p m}$} & $\mathbf{C O}_{3} \mathbf{H C O}_{\mathbf{3}}^{-}$ & $\mathbf{C l}^{-}$ & $\mathbf{S O}_{\mathbf{4}}{ }^{-}$ & $\mathbf{C a}^{++}$ & $\mathbf{M g}^{++}$ & $\mathbf{N a}^{+}$ & $\mathbf{K}^{+}$ \\
\hline $\begin{array}{l}\text { El-Qantara } \\
\text { Sharq }\end{array}$ & 7.14 & 1152.00 & - & 1.30 & 13.20 & 2.50 & 7.30 & 2.10 & 7.37 & 0.23 \\
El-Maghara & 7.32 & 2547.15 & - & 4.26 & 23.59 & 11.44 & 11.45 & 9.64 & 17.31 & 0.89 \\
Siwa Oasis & 7.41 & 2155.00 & - & 3.63 & 16.87 & 14.43 & 7.27 & 4.50 & 22.12 & 1.04 \\
\hline
\end{tabular}

Table (5). Means of the meteorological data of El-Qantara Sharq location during the seasons of 2012/2013 and 2013/2014.

\begin{tabular}{|c|c|c|c|c|c|c|c|c|}
\hline \multirow[t]{2}{*}{ Month } & & \multicolumn{3}{|c|}{$\begin{array}{l}\text { Air temperature } \\
\left({ }^{\circ} \mathrm{C}\right)\end{array}$} & \multirow[t]{2}{*}{$\begin{array}{c}\text { Solar } \\
\left(\mathbf{M J} / \mathbf{m}^{2}\right)\end{array}$} & \multirow[t]{2}{*}{$\begin{array}{l}\text { Precipitation } \\
\text { (mm) }\end{array}$} & \multirow{2}{*}{$\begin{array}{l}\text { Relative } \\
\text { humidity } \\
\text { (fraction) }\end{array}$} & \multirow[t]{2}{*}{$\begin{array}{r}\text { Wind } \\
(\mathrm{m} / \mathrm{s})\end{array}$} \\
\hline & & Max. & Min. & Average & & & & \\
\hline Winter & 21to31December & 20.05 & 8.64 & 14.35 & 11.23 & 0.56 & 0.6564 & 1.34 \\
\hline \multirow[t]{3}{*}{ months } & January & 19.73 & 8.49 & 14.11 & 12.75 & 0.85 & 0.6747 & 1.44 \\
\hline & February & 21.72 & 8.71 & 15.22 & 16.25 & 0.54 & 0.6379 & 1.57 \\
\hline & 1 to $19-20$ March & 25.76 & 10.81 & 18.29 & 19.16 & 0.22 & 0.5223 & 1.91 \\
\hline Mean & & 21.82 & 9.16 & 15.49 & 14.85 & 0.54 & 0.6228 & 1.57 \\
\hline \multirow{4}{*}{$\begin{array}{l}\text { Spring } \\
\text { months }\end{array}$} & 20-21 to31 March & 27.11 & 9.31 & 18.21 & 23.99 & 0.00 & 0.5633 & 1.94 \\
\hline & April & 28.70 & 11.30 & 20.00 & 25.61 & 0.04 & 0.5461 & 1.89 \\
\hline & May & 33.04 & 14.82 & 23.94 & 27.44 & 0.37 & 0.5228 & 1.82 \\
\hline & 1 to 20 June & 34.55 & 16.00 & 25.28 & 28.84 & 0.02 & 0.5316 & 1.87 \\
\hline Mean & & 30.85 & 12.86 & 21.86 & 26.47 & 0.12 & 0.5410 & 1.88 \\
\hline \multirow{4}{*}{$\begin{array}{c}\text { Summer } \\
\text { months }\end{array}$} & 21 to 30 June & 36.11 & 16.41 & 26.26 & 29.51 & 0.01 & 0.5905 & 1.72 \\
\hline & July & 35.62 & 17.54 & 26.58 & 28.93 & 0.00 & 0.6114 & 1.70 \\
\hline & August & 36.82 & 18.50 & 27.66 & 27.00 & 0.00 & 0.6175 & 1.62 \\
\hline & 1to22 September & 34.60 & 18.54 & 26.57 & 23.88 & 0.00 & 0.6351 & 1.68 \\
\hline Mean & & 35.79 & 17.75 & 26.77 & 27.33 & 0.00 & 0.6136 & 1.68 \\
\hline \multirow{3}{*}{$\begin{array}{l}\text { Autumn } \\
\text { months }\end{array}$} & 23to30 September & 30.69 & 15.75 & 23.22 & 20.19 & 0.03 & 0.6630 & 1.52 \\
\hline & October & 29.99 & 15.71 & 22.85 & 18.52 & 0.01 & 0.6313 & 1.72 \\
\hline & November & 26.81 & 14.13 & 20.47 & 13.52 & 0.28 & 0.6448 & 1.46 \\
\hline Mean & & 29.16 & 15.20 & 22.18 & 17.41 & 0.12 & 0.6464 & 1.57 \\
\hline
\end{tabular}


Table (6). Means of the meteorological data of El-Maghara location during the seasons of 2012/2013 and 2013/2014.

\begin{tabular}{|c|c|c|c|c|c|c|c|c|}
\hline \multirow[t]{2}{*}{ Month } & & \multicolumn{3}{|c|}{$\begin{array}{c}\text { Air temperature } \\
\left({ }^{\circ} \mathrm{C}\right)\end{array}$} & \multirow[t]{2}{*}{$\begin{array}{c}\text { Solar } \\
\left(\mathbf{M J} / \mathbf{m}^{2}\right)\end{array}$} & \multirow[t]{2}{*}{$\begin{array}{l}\text { Precipitation } \\
(\mathbf{m m})\end{array}$} & \multirow{2}{*}{$\begin{array}{l}\text { Relative } \\
\text { humidity } \\
\text { (fraction) }\end{array}$} & \multirow[t]{2}{*}{$\begin{array}{r}\text { Wind } \\
(\mathbf{m} / \mathbf{s})\end{array}$} \\
\hline & & Max. & Min. & Average & & & & \\
\hline \multirow{4}{*}{$\begin{array}{l}\text { Winter } \\
\text { months }\end{array}$} & 21to31December & 17.52 & 4.88 & 11.20 & 12.77 & 0.01 & 0.62 & 2.17 \\
\hline & January & 18.17 & 5.62 & 11.90 & 13.84 & 0.20 & 0.58 & 2.36 \\
\hline & February & 20.54 & 6.30 & 13.42 & 18.06 & 0.16 & 0.52 & 2.53 \\
\hline & 1 to $19-20$ March & 23.31 & 8.01 & 15.66 & 21.83 & 0.32 & 0.46 & 3.28 \\
\hline Mean & & 19.89 & 6.20 & 13.05 & 16.63 & 0.17 & 0.55 & 2.59 \\
\hline \multirow{4}{*}{$\begin{array}{l}\text { Spring } \\
\text { months }\end{array}$} & 20-21to31 March & 25.20 & 6.99 & 16.10 & 25.45 & 0.00 & 0.47 & 2.79 \\
\hline & April & 28.72 & 9.45 & 19.09 & 27.71 & 0.00 & 0.40 & 3.07 \\
\hline & May & 33.66 & 13.49 & 23.58 & 29.23 & 0.00 & 0.36 & 3.11 \\
\hline & 1 to 20 June & 36.36 & 14.87 & 25.62 & 30.83 & 0.00 & 0.37 & 2.95 \\
\hline Mean & & 30.99 & 11.20 & 21.10 & 28.31 & 0.00 & 0.40 & 2.98 \\
\hline \multirow{4}{*}{$\begin{array}{l}\text { Summer } \\
\text { months }\end{array}$} & 21 to 30 June & 36.72 & 15.61 & 26.17 & 30.80 & 0.00 & 0.41 & 2.60 \\
\hline & July & 36.90 & 15.57 & 26.24 & 30.26 & 0.00 & 0.45 & 2.64 \\
\hline & August & 36.55 & 15.94 & 26.25 & 28.45 & 0.00 & 0.45 & 2.50 \\
\hline & 1to22 September & 34.59 & 15.02 & 24.81 & 25.13 & 0.00 & 0.56 & 2.71 \\
\hline Mean & & 36.19 & 15.54 & 25.87 & 28.66 & 0.00 & 0.47 & 2.61 \\
\hline \multirow{3}{*}{$\begin{array}{l}\text { Autumn } \\
\text { months }\end{array}$} & 23to30 September & 32.71 & 14.15 & 23.43 & 22.65 & 0.00 & 0.59 & 2.32 \\
\hline & October & 29.54 & 11.93 & 20.74 & 19.79 & 0.01 & 0.57 & 2.35 \\
\hline & November & 25.04 & 10.79 & 17.92 & 14.82 & 0.04 & 0.57 & 2.16 \\
\hline Mean & & 29.10 & 12.29 & 20.70 & 19.09 & 0.02 & 0.58 & 2.28 \\
\hline
\end{tabular}


Table (7). Means of the meteorological data of Siwa Oasis location during the seasons of 2012/2013 and 2013/2014.

\begin{tabular}{|c|c|c|c|c|c|c|c|c|}
\hline \multirow[t]{2}{*}{ Month } & & \multicolumn{3}{|c|}{$\begin{array}{c}\text { Air temperature } \\
\left({ }^{\circ} \mathrm{C}\right)\end{array}$} & \multirow[t]{2}{*}{$\begin{array}{c}\text { Solar } \\
\left(\mathbf{M J} / \mathbf{m}^{2}\right)\end{array}$} & \multirow[t]{2}{*}{$\begin{array}{l}\text { Precipitation } \\
(\mathbf{m m})\end{array}$} & \multirow{2}{*}{$\begin{array}{c}\text { Relative } \\
\text { humidity } \\
\text { (fraction) }\end{array}$} & \multirow[t]{2}{*}{$\begin{array}{r}\text { Wind } \\
(\mathbf{m} / \mathbf{s})\end{array}$} \\
\hline & & Max. & Min. & Average & & & & \\
\hline Winter & 21to31December & 19.21 & 8.13 & 13.67 & 12.73 & 0.01 & 0.6293 & 3.28 \\
\hline \multirow{3}{*}{ months } & January & 19.24 & 7.86 & 13.55 & 13.89 & 0.20 & 0.5438 & 3.03 \\
\hline & February & 21.74 & 8.64 & 15.19 & 18.77 & 0.02 & 0.4591 & 3.44 \\
\hline & 1 to $19-20$ March & 25.95 & 11.17 & 18.56 & 22.45 & 0.00 & 0.3835 & 4.18 \\
\hline Mean & & 21.54 & 8.95 & 15.24 & 16.96 & 0.01 & 0.5039 & 3.48 \\
\hline \multirow{4}{*}{$\begin{array}{l}\text { Spring } \\
\text { months }\end{array}$} & 20-21 to31 March & 29.27 & 12.37 & 20.82 & 25.27 & 0.00 & 0.3070 & 4.08 \\
\hline & April & 30.69 & 12.67 & 21.68 & 27.37 & 0.01 & 0.3323 & 3.57 \\
\hline & May & 35.87 & 18.25 & 27.06 & 28.59 & 0.06 & 0.2721 & 3.84 \\
\hline & 1 to 20 June & 37.62 & 18.88 & 28.25 & 29.93 & 0.02 & 0.2963 & 3.94 \\
\hline Mean & & 33.36 & 15.54 & 24.45 & 27.79 & 0.02 & 0.3019 & 3.86 \\
\hline \multirow{4}{*}{$\begin{array}{l}\text { Summer } \\
\text { months }\end{array}$} & 21 to 30 June & 39.24 & 18.44 & 28.84 & 30.48 & 0 . & 0.3143 & 3.72 \\
\hline & July & 38.68 & 18.47 & 28.58 & 29.82 & 0.00 & 0.3670 & 3.46 \\
\hline & August & 38.93 & 19.35 & 29.14 & 28.00 & 0.00 & & 3.25 \\
\hline & 1to22 September & 37.50 & 18.51 & 28.01 & 25.17 & 0.00 & 0.3948 & 3.48 \\
\hline Mean & & 38.59 & 18.69 & 28.64 & 28.37 & 0.00 & 598 & 3.48 \\
\hline \multirow{3}{*}{$\begin{array}{l}\text { Autumn } \\
\text { months }\end{array}$} & 23to30 September & 34.54 & 17.83 & 26.19 & 23.01 & 0.00 & 0.4302 & 3.08 \\
\hline & October & 30.62 & 14.86 & 22.74 & 19.74 & 0.00 & 0.5082 & 3.32 \\
\hline & November & 26.07 & 12.25 & 19.16 & 15.01 & 0.01 & 0.5411 & 2.87 \\
\hline Mean & & 30.41 & 14.98 & 22.70 & 19.25 & 0.00 & 0.4932 & 3.09 \\
\hline
\end{tabular}

2. Quantity Parameters of Three-lobed Sage Herb

- Number of cuts per season.

- Fresh weight of herb/plant (g).

- Dry weight of herb/plant (g).

- Dry weight of herb/fed (ton).

\section{Quality Parameters of Essential Oil of Three-lobed Sage Herb}

3.1. Essential oil percentage

Essential oil percentage was determined in the air dried herb by hydrodistillation for 3 hours using a Clevenger type apparatus. The essential oil (\%) was calculated as a relative percentage (v/w) (British Pharmacopoeia, 1963).

3.2. Essential oil yield per plant

Essential oil yield per plant (ml) was calculated as follows: oil percentage $\times$ herb dry weight ( $\mathrm{g} /$ plant)

$$
100
$$




\subsection{Essential oil yield per feddan}

Essential oil yield per feddan (1) was calculated as follows :essential oil yield per plant $\times$ number of plants/feddan (11200 plants/feddan).

\subsection{Essential oil chemical constituents}

The GC-MS analysis of essential oils was conducted in the second season using Gas Chromatography-Mass Spectrometry instrument stands at the Laboratory of Medicinal and Aromatic Plants, National Research Center, Egypt with the following specifications. Instrument: a TRACE GC Ultra Gas Chromatographs (THERMO Scientific Corp., USA), coupled with a THERMO mass spectrometer detector (ISQ Single Quadrupole Mass Spectrometer). The GC-MS system was equipped with a TR-5MS column (30 m x $0.32 \mathrm{~mm}$ i.d., $0.25 \mu \mathrm{m}$ film thickness). Analyses were carried out using helium as carrier gas at a flow rate of $1.3 \mathrm{ml} / \mathrm{min}$ at a split ratio of $1: 10$ and the following temperature program: $80^{\circ} \mathrm{C}$ for $1 \mathrm{~min}$; rising at $4^{\circ} \mathrm{C} / \mathrm{min}$ to $300^{\circ} \mathrm{C}$ and held for $1 \mathrm{~min}$. The injector and detector were held at 220 and $200^{\circ} \mathrm{C}$, respectively. Diluted samples $(1: 10$ hexane, v/v) of $1 \mu \mathrm{L}$ of the mixtures were always injected. Mass spectra were obtained by electron ionization (EI) at $70 \mathrm{eV}$, using a spectral range of $\mathrm{m} / \mathrm{z} 40-450$. The separated components of the essential oil were identified by matching with the National Institute of Standards and Technology (NIST) published.

\section{RESULTS AND DISCUSSION}

\section{Effect of Different Locations on Quantity Parameters of Three-lobed Sage Herb}

Data of the effect of different planting locations on quantity parameters of three-lobed sage herb are shown in tables $(8,9$ and 10).

The obtained results indicated that all herb quantity parameters (number of cuts per season, fresh weight of herb/plant, dry weight of herb/plant and dry weight of herb/fed) were affected and varied according to the different planting locations.

These variations in herb productivity may be due the existence of a wide range of climatic conditions among the different studied locations. At North Sinai Governorate, there was an increment in the yield quantity parameters accompanied with increasing air temperature and solar radiation, especially at southern locations in Sinai where the air temperature and solar radiation are increased (Tables 5 and 6). The significantly highest yield parameters were obtained at El-Maghara location at the middle of Sinai Peninsula $\left(30.71^{\circ} \mathrm{N}\right.$ and $\left.33.33^{\circ} \mathrm{E}\right)$, while lower parameters were recorded at El-Qantara Sharq at the North of Sinai $\left(30.75^{\circ} \mathrm{N}\right.$ and $\left.32.50^{\circ} \mathrm{E}\right)$ for the three cuts in both seasons.

On the contrary, at Siwa Oasis location, which is located in the western desert of Egypt $\left(29.21^{\circ} \mathrm{N}\right.$ and $25.40^{\circ} \mathrm{E}, 300 \mathrm{~km}$ South of the Mediterranean Sea and $-19 \mathrm{~m}$ below sea level), the extremely high air 
temperature during summer months (Table 7) led to a heat or thermal stress on plants and therefore, the lowest yield parameters were detected at this location; i.e. lowest number of cuts per season (two cuts per season) as well as the lowest fresh and dry weights of herb/plant during both seasons.

Similar results were obtained by Roberts and Summerfield (1987), who mentioned that, the rate of plant development is a function of temperature and usually increases linearly from above the species-specific base temperature until the optimum temperature. Kintzios (2003), on wild Salvia fruticosa plants, reported that the plants were affected by the mean annual temperature and the total annual sunshine at the different growing locations. Mastro et al. (2006), Zawislak (2006) and Hückstädt et al. (2013) found that, the interactive effects of light with temperature play an important role on plant growth of Salvia officinalis. Also, these results are in harmony with the earlier publications on cultivation of wild three-lobed sage plants by Putievsky et al. (1986), who found that the fresh matter yield in the first year of growth increased in each harvest, but from the second year there was a special pattern. In spring, the fresh yield was the highest.

In general, the superiority of North Sinai Governorate locations for cultivation and production of the highest herb yield may be due to that the environmental conditions at North Sinai are to some extent similar to the environmental conditions of some countries like Palestine, Syria, Lebanon and Jordan, where three-lobed sage plants are grown as wild plants (Khan and Ather, 2006).

Table (8). Effect of different locations on fresh weight of herb/plant (g) of Salvia fruticosa during the two successive seasons (2012/2013 and 2013/2014).

\begin{tabular}{lcccccc}
\hline Location & \multicolumn{3}{c}{$\begin{array}{c}\text { First season } \\
(\mathbf{2 0 1 2 / 2 0 1 3})\end{array}$} & \multicolumn{3}{c}{$\begin{array}{c}\text { Second season } \\
(\mathbf{2 0 1 3} / \mathbf{2 0 1 4})\end{array}$} \\
\cline { 2 - 7 } & \multicolumn{3}{c}{ Harvesting date } & \multicolumn{3}{c}{ Harvesting date } \\
\cline { 2 - 7 } & July & November & March & July & November & March \\
& $\mathbf{2 0 1 2}$ & $\mathbf{2 0 1 2}$ & $\mathbf{2 0 1 3}$ & $\mathbf{2 0 1 3}$ & $\mathbf{2 0 1 3}$ & $\mathbf{2 0 1 4}$ \\
& (summer cut) & (autumn cut) & (spring cut) & (summer cut) & (autumn cut) & (spring cut) \\
\hline El-Qantara Sharq & 133.87 & 207.87 & 270.23 & 134.04 & 173.33 & 216.40 \\
El-Maghara & 250.18 & 293.00 & 345.03 & 290.00 & 330.11 & 386.09 \\
Siwa Oasis & - & 151.67 & 250.55 & - & 146.21 & 210.37 \\
LSD 0.05 & 1.430 & 1.674 & 5.446 & 2.338 & 1.635 & 2.921 \\
\hline
\end{tabular}


Table (9). Effect of different locations on dry weight of herb/plant (g) of Salvia fruticosa during the two successive seasons (2012/2013 and 2013/2014).

\section{Location}

First season

Second season

$(2012 / 2013)$

$(2013 / 2014)$

\begin{tabular}{|c|c|c|c|c|c|c|}
\hline & \multicolumn{3}{|c|}{ Harvesting date } & \multicolumn{3}{|c|}{ Harvesting date } \\
\hline & $\begin{array}{c}\text { July } \\
2012 \\
\text { (summer cut) }\end{array}$ & $\begin{array}{c}\text { November } \\
2012 \\
\text { (autumn cut) }\end{array}$ & $\begin{array}{c}\text { March } \\
2013 \\
\text { spring cut) }\end{array}$ & \begin{tabular}{|c|} 
July \\
2013 \\
(summer cut
\end{tabular} & $\begin{array}{c}\text { November } \\
2013 \\
\text { (autumn cut) }\end{array}$ & $\begin{array}{c}\text { March } \\
2014 \\
\text { (spring cut) }\end{array}$ \\
\hline El-Qantara Sharq & 43.00 & 65.13 & 78.97 & 45.61 & 58.09 & 70.12 \\
\hline El-Maghara & 85.15 & 106.38 & 118.20 & 104.50 & 121.00 & 132.11 \\
\hline Siwa Oasis & - & 39.33 & 73.13 & - & 34.41 & 61.07 \\
\hline LSD 0.05 & 0.530 & 2.506 & 2.160 & 3.605 & 1.208 & 2.021 \\
\hline
\end{tabular}

Table (10). Effect of different locations on dry weight of herb/fed (ton) of Salvia fruticosa during the two successive seasons (2012/2013 and 2013/2014).

\begin{tabular}{|c|c|c|c|c|c|c|c|c|}
\hline \multirow[t]{3}{*}{ Location } & \multicolumn{4}{|c|}{$\begin{array}{l}\text { First season } \\
(2012 / 2013)\end{array}$} & \multicolumn{4}{|c|}{$\begin{array}{c}\text { Second season } \\
(2013 / 2014)\end{array}$} \\
\hline & \multicolumn{3}{|c|}{ Harvesting date } & \multirow[b]{2}{*}{$\begin{array}{c}\text { Total } \\
\text { yield } \\
\text { per } \\
\text { season }\end{array}$} & \multicolumn{3}{|c|}{ Harvesting date } & \multirow[b]{2}{*}{$\begin{array}{c}\text { Total } \\
\text { yield } \\
\text { per } \\
\text { season }\end{array}$} \\
\hline & $\begin{array}{c}\text { July } \\
2012 \\
\text { (summer cut) }\end{array}$ & $\begin{array}{c}\text { November } \\
2012 \\
\text { (autumn cut) }\end{array}$ & $\begin{array}{c}\text { March } \\
2013 \\
\text { spring cut) }\end{array}$ & & $\begin{array}{c}\text { July } \\
2013 \\
\text { (summer } \\
\text { cut) }\end{array}$ & $\begin{array}{l}\text { November } \\
2013 \\
\text { (autumn } \\
\text { cut) }\end{array}$ & $\begin{array}{l}\text { March } \\
2014 \\
\text { (spring } \\
\text { cut) }\end{array}$ & \\
\hline $\begin{array}{l}\text { El-Qantara } \\
\text { Sharq }\end{array}$ & 0.48 & 0.73 & 0.88 & 2.09 & 0.51 & 0.65 & 0.79 & 1.95 \\
\hline El-Maghara & 0.95 & 1.19 & 1.32 & 3.46 & 1.17 & 1.36 & 1.48 & 4.01 \\
\hline Siwa Oasis & - & 0.44 & 0.82 & 1.26 & - & 0.39 & 0.68 & 1.07 \\
\hline LSD 0.05 & 0.010 & 0.002 & 0.002 & 0.002 & 0.004 & 0.100 & 0.190 & 0.072 \\
\hline
\end{tabular}

2. Effect of the Different Planting Locations on Quality Parameters of Essential Oil of Three-lobed Sage Herb

Data presented in tables $(11,12,13$ and 14) show the effect of different planting locations on quality parameters of essential oil of threelobed sage herb. The obtained data showed that the quality parameters of the herb (essential oil percentage, essential oil yield per plant or per feddan and chemical constituents of essential oil) were affected and varied according to different planting locations and harvesting time. 


\subsection{Essential oil percentage}

In both seasons, the significantly highest essential oil percentage was recorded at Siwa Oasis location, while the lowest one was detected at El-Qantara Sharq location for all cuts. Also, the highest essential oil percentage was found in the summer cut followed by autumn cut, while the lowest percentage was observed in the spring cut during both seasons. These results proved the strongly positive correlation between the increment of air temperature, solar radiation and volatile oil synthesis in the plant leaves.

Similar results were obtained by Mastro et al. (2006), Zawislak (2006) and Hückstädt et al. (2013) on common sage (Salvia officinalis). On cultivated wild three-lobed sage plants, Putievsky et al. (1986) found that from the second year in spring the essential oil content was quite low. Moreover, these results were approved by several author, who reported that the essential oil content of wild three-lobed sage plants is largely affected by growing location and different environmental conditions (Müller et al., 1997; Karousou et al., 1998; Aziz et al., 2008 and Cvetkovikj et al., 2015).

Also, these obtained values of essential oil percentage (ranging from 1.17 to $3.12 \%$ ) are in agreement with the Standards of the European Pharmacopoeia (2005), which concluded that the whole drug of three-lobed sage should contain not less than $18 \mathrm{ml} / \mathrm{kg}$ of essential oil as calculated with reference to the anhydrous drug.

Table (11). Effect of different locations on essential oil percentage of Salvia fruticosa during the two successive seasons (2012/2013 and 2013/2014).

\begin{tabular}{lcccccc}
\hline Location & \multicolumn{3}{c}{ First season } & \multicolumn{3}{c}{ Second season } \\
\cline { 2 - 7 } & \multicolumn{3}{c}{ Harvesting date } & \multicolumn{3}{c}{ Harvesting date } \\
\cline { 2 - 7 } & July & November & March & July & November & March \\
& $\mathbf{2 0 1 2}$ & $\mathbf{2 0 1 2}$ & $\mathbf{2 0 1 3}$ & $\mathbf{2 0 1 3}$ & $\mathbf{2 0 1 3}$ & $\mathbf{2 0 1 4}$ \\
& (summer cut) & (autumn cut) & (spring cut) & (summer cut) & (autumn cut) & (spring cut) \\
& 2.05 & 1.95 & 1.24 & 2.10 & 1.90 & 1.20 \\
El-Qantara Sharq & 3.04 & 2.26 & 1.19 & 3.12 & 2.21 & 1.17 \\
El-Maghara & - & 2.52 & 1.43 & - & 2.31 & 1.49 \\
Siwa Oasis & 0.130 & 0.002 & 0.002 & 0.004 & 0.002 & 0.033 \\
LSD 0.05 & & & & & & \\
\hline
\end{tabular}

\subsection{Essential oil yield}

In both seasons, the significantly highest essential oil yield $(\mathrm{ml} /$ plant) was resulted from El-Maghara location followed by El-Qantara Sharq. This may be attributed to that plants at this location recorded its highest dry weight of herb per plant and/or essential oil percentage. These results coincided with the standards of the European Pharmacopoeia (2005), which concluded that the cut drug of three-lobed sage should contain not less than 
$12 \mathrm{ml} / \mathrm{kg}$ of essential oil. Also, the essential oil yield (l/ feddan) had the same trend as shown with $\mathrm{ml} / \mathrm{plant}$.

Table (12). Effect of different locations on essential oil yield per plant (ml) of Salvia fruticosa during the two successive seasons (2012/2013 and 2013/2014).

\begin{tabular}{lcccccc}
\hline Location & \multicolumn{3}{c}{ First season } & \multicolumn{3}{c}{ Second season } \\
\cline { 2 - 7 } & \multicolumn{3}{c}{ Harvesting date } & \multicolumn{3}{c}{ Harvesting date } \\
\cline { 2 - 7 } & July & November & March & July & November & March \\
& $\mathbf{2 0 1 2}$ & $\mathbf{2 0 1 2}$ & $\mathbf{2 0 1 3}$ & $\mathbf{2 0 1 3}$ & $\mathbf{2 0 1 3}$ & $\mathbf{2 0 1 4}$ \\
& (summer & (autumn & (spring & (summer & (autumn & (spring \\
& cut) & cut) & cut) & cut) & cut) & cut) \\
\hline El-Qantara Sharq & 0.88 & 1.27 & 0.98 & 0.96 & 1.10 & 0.84 \\
El-Maghara & 2.59 & 2.40 & 1.41 & 3.26 & 2.67 & 1.55 \\
Siwa Oasis & - & 0.99 & 1.05 & - & 0.80 & 0.91 \\
LSD 0.05 & 0.004 & 0.002 & 0.007 & 0.004 & 0.002 & 0.002 \\
\hline
\end{tabular}

Table (13). Effect of different locations on essential oil yield (1/ feddan) of Salvia fruticosa during the two successive seasons (2012/2013 and 2013/2014).

\begin{tabular}{|c|c|c|c|c|c|c|c|c|}
\hline & \multicolumn{3}{|c|}{ Harvesting date } & \multirow[b]{2}{*}{$\begin{array}{c}\text { Total } \\
\text { yield } \\
\text { per } \\
\text { season }\end{array}$} & \multicolumn{3}{|c|}{ Harvesting date } & \multirow[b]{2}{*}{$\begin{array}{c}\text { Total } \\
\text { yield } \\
\text { per season }\end{array}$} \\
\hline & $\begin{array}{c}\text { July } \\
2012 \\
\text { (summer } \\
\text { cut) }\end{array}$ & $\begin{array}{c}\text { November } \\
2012 \\
\text { (autumn } \\
\text { cut) }\end{array}$ & $\begin{array}{c}\text { March } \\
2013 \\
\text { (spring } \\
\text { cut) }\end{array}$ & & $\begin{array}{c}\text { July } \\
2013 \\
\text { (summer } \\
\text { cut) }\end{array}$ & $\begin{array}{c}\text { November } \\
2013 \\
\text { (autumn } \\
\text { cut) }\end{array}$ & $\begin{array}{c}\text { March } \\
2014 \\
\text { (spring } \\
\text { cut) }\end{array}$ & \\
\hline $\begin{array}{l}\text { El-Qantara } \\
\text { Sharq }\end{array}$ & 9.86 & 14.22 & 10.98 & 35.06 & 10.75 & 12.32 & 9.41 & 32.48 \\
\hline El-Maghara & 29.01 & 26 & 15.79 & 71. & 36.51 & 29.90 & 17.36 & 83.77 \\
\hline Siwa Oasis & - & 11.09 & 11.76 & 22.85 & - & 8.96 & 10.19 & 19.15 \\
\hline LSD 0.05 & 0.004 & 0.140 & 0.072 & 0.002 & 0.004 & 0.002 & 0.002 & 0.072 \\
\hline
\end{tabular}

\subsection{Essential oil constituents}

The results revealed that, the constituents of Salvia fruticosa volatile oil had been affected by the different planting locations and harvesting time. The compound of 1,8-cineole was the main dominant chemical constituent in the oil (Table 14). These results can be summarized as follows:

At El-Qantara Sharq location the most abundant components in summer cut oil were 1,8-cineole (44.18\%), camphor (14.22\%), $\beta$-pinene (7.91\%), camphene $(5.47 \%)$ and $\alpha$-pinene $(5.06 \%)$ while in autumn cut oil 
the abundant constituents were 1,8-cineole (42.91\%), camphor $(10.39 \%), \beta$ pinene $(8.45 \%)$, caryophyllene $(6.95 \%)$, camphene $(4.55 \%)$ and $\alpha$-pinene (4.49\%).

At El-Maghara location the major components in summer cut oil were 1,8-cineole (31.87\%), camphor (23.68\%), camphene (8.72\%), $\beta$-pinene $(6.86 \%)$ and $\alpha$-pinene $(5.66 \%)$ while in autumn cut oil the major components were 1,8 -cineole $(44.70 \%)$, camphor $(16.57 \%), \beta$-pinene $(6.66 \%)$, camphene $(5.62 \%)$ and $\alpha$-pinene $(5.32 \%)$.

At Siwa Oasis location the dominant components in autumn cut oil were 1,8-cineole (45.67\%), camphor (12.23\%), $\beta$-pinene $(9.20 \%), \alpha$-pinene (4.63\%) and camphene $(4.21 \%)$ while in spring cut oil the major components were 1,8-cineole $(39.09 \%)$, caryophyllene $(11.50 \%), \beta$-pinene $(9.94 \%)$, camphor $(5.13 \%)$ and $\alpha$-myrcene $(4.04 \%)$.

These results coincided with those obtained by Müller-Riebau et al. (1997), Karousou et al. (1998), Aziz et al. (2008) and Cvetkovikj et al. (2015), who stated that the essential oil chemical composition of wild threelobed sage plants was affected by the different geographical growing locations and environmental conditions.

Also, it is clear that the main component of the essential oil was 1,8 cineole (ranging from 31.87-45.67\%) which has the pharmaceutical effect, differentiating it from thujone rich Salvia officinalis cultivars. The current analysis of Salvia fruticosa oil indicated that the amounts of $\alpha$ - and $\beta$ thujone, the major components in Salvia officinalis were below $2.80 \%$. Nowadays, due to the toxicity issues associated with thujone, low thujone sources of sage leaf and sage oil are finding increasing market interest (International Trade Center, 2015).

Finally, from the aforementioned data, it is obvious that the highest herb quantity parameters (number of cuts per season, fresh weight of herb per plant, dry weight of herb per plant and per feddan) and quality parameters (essential oil yield per plant and per feddan with a suitable content of 1,8-cineole) were detected at El-Maghara location at North Sinai Governorate as compared to other locations in this experiment. Therefore, this kind of research studies is very important for planners of agriculture policy in Egypt for expansion of sowing the suitable plants in suitable places thereby increasing the farmers' income which may reflect on the national income. 
Table (14). Chemical constituents (\%) of essential oil at the different locations.

\begin{tabular}{|c|c|c|c|c|c|c|c|c|}
\hline \multirow[t]{3}{*}{ No. } & \multirow[t]{3}{*}{ R.T. } & \multirow[t]{3}{*}{ Constituents } & \multirow{2}{*}{\multicolumn{2}{|c|}{$\begin{array}{c}\text { El-Qantara Sharq } \\
\text { Harvesting date }\end{array}$}} & \multicolumn{2}{|c|}{ El-Maghara } & \multicolumn{2}{|c|}{ Siwa Oasis } \\
\hline & & & & & Harves & ting date & Harvesti & g date \\
\hline & & & $\begin{array}{c}\text { July } \\
2013 \\
\text { (summer } \\
\text { cut) }\end{array}$ & $\begin{array}{l}\text { November } \\
2013 \\
\text { (autumn } \\
\text { cut) }\end{array}$ & $\begin{array}{c}\text { July } \\
2013 \\
\text { (summer } \\
\text { cut) }\end{array}$ & $\begin{array}{l}\text { November } \\
2013 \\
\text { (autumn } \\
\text { cut) }\end{array}$ & $\begin{array}{c}\text { November } \\
2013 \\
\text { (autumn } \\
\text { cut) }\end{array}$ & $\begin{array}{c}\text { March } \\
2014 \\
\text { (spring } \\
\text { cut) }\end{array}$ \\
\hline 1 & 4.52 & Tricyclene & - & - & 0.63 & 0.43 & - & - \\
\hline 2 & 4.57 & 2-thujene & 0.51 & 0.60 & - & - & 0.47 & 0.55 \\
\hline 3 & 4.76 & $\alpha$-pinene & 5.06 & 4.49 & 5.66 & 5.32 & 4.63 & 2.90 \\
\hline 4 & 5.21 & Camphene & 5.47 & 4.55 & 8.72 & 5.62 & 4.21 & 1.91 \\
\hline 5 & 5.80 & Sabinene & 0.13 & 0.31 & 0.11 & 0.06 & 0.18 & 0.36 \\
\hline 6 & 5.96 & $\beta$-pinene & 7.91 & 8.45 & 6.86 & 6.66 & 9.20 & 9.94 \\
\hline 7 & 6.21 & $\alpha$-myrcene & 2.51 & 3.78 & 1.61 & 2.15 & 3.16 & 4.04 \\
\hline 8 & 6.81 & L-phellandrene & 0.05 & 0.04 & - & - & - & - \\
\hline 9 & 7.12 & $\alpha$-terpinene & 0.27 & 0.22 & 0.16 & 0.17 & 0.22 & 0.34 \\
\hline 10 & 7.44 & p-cymene & 0.20 & 0.12 & 0.42 & 0.71 & 0.21 & 0.35 \\
\hline 11 & 7.53 & D-limonene & 1.99 & 1.42 & 2.74 & 1.78 & 1.65 & 0.87 \\
\hline 12 & 7.67 & 1,8-cineole & 44.18 & 42.91 & 31.87 & 44.70 & 45.67 & 39.09 \\
\hline 13 & 8.53 & ç-terpinene & 0.49 & 0.60 & 0.26 & 0.17 & 0.46 & 1.34 \\
\hline 14 & 9.04 & 4-thujanol & 0.22 & 0.70 & 0.18 & 0.11 & 0.31 & 0.81 \\
\hline 15 & 9.50 & $\alpha$-terpinolene & 0.18 & 0.15 & 0.19 & 0.06 & 0.17 & 0.16 \\
\hline 16 & 10.13 & L-linalool & 0.17 & 0.13 & 0.34 & 0.21 & 0.17 & 0.16 \\
\hline 17 & 10.21 & Terpineol,cis-á- & 0.12 & 0.24 & 0.12 & 0.07 & 0.16 & 0.27 \\
\hline 18 & 10.47 & $\beta$-thujone & 1.71 & 1.19 & 1.94 & 1.65 & 1.57 & 0.46 \\
\hline 19 & 10.92 & $\alpha$-thujone & 0.67 & 0.52 & 0.86 & 0.74 & 0.69 & 0.57 \\
\hline 20 & 11.81 & Pinocarveol & - & - & 0.06 & 0.07 & - & - \\
\hline 21 & 12.18 & Camphor & 14.22 & 10.39 & 23.68 & 16.57 & 12.23 & 5.13 \\
\hline 22 & 12.45 & $\begin{array}{c}2- \\
\text { norbornanol,2,3,3- } \\
\text { trimethyl- }\end{array}$ & - & - & - & 0.04 & - & - \\
\hline 23 & 12.68 & Pinocamphone & 0.48 & 0.80 & 0.45 & 0.55 & 0.61 & 0.93 \\
\hline 24 & 13.14 & Borneol & 2.76 & 1.91 & 3.33 & 2.96 & 2.26 & 2.00 \\
\hline 25 & 13.36 & 3-pinanone,cis & 0.17 & 0.33 & - & - & 0.25 & 0.45 \\
\hline 26 & 13.45 & 4-terpineol & 0.81 & 0.43 & 0.82 & 0.61 & 0.66 & 0.32 \\
\hline 27 & 14.13 & p-menth-1-en-8-ol & 2.68 & 2.36 & 0.97 & 2.10 & 2.91 & 2.93 \\
\hline 28 & 16.19 & Linalyl acetate & 0.23 & 0.17 & 0.77 & 0.29 & 0.22 & - \\
\hline 29 & 17.73 & L-bornyl acetate & 1.15 & 0.83 & 2.13 & 0.88 & 0.72 & 0.44 \\
\hline 30 & 18.96 & Ocimenyl acetate & 0.08 & 0.04 & 0.11 & 0.12 & 0.08 & - \\
\hline 31 & 19.43 & $\begin{array}{l}\text { 2-pinen-10- } \\
\text { ol,acetate }\end{array}$ & 0.05 & 0.07 & 0.06 & - & - & - \\
\hline
\end{tabular}


Table (14) Cont.

\begin{tabular}{|c|c|c|c|c|c|c|c|c|}
\hline 32 & 20.07 & $\begin{array}{c}\text { Exo-2- } \\
\text { hydroxycineole } \\
\text { acetate }\end{array}$ & 0.05 & - & 0.05 & - & 0.07 & - \\
\hline 33 & 20.38 & $\alpha$-terpinenyl acetae & 2.20 & 1.07 & 2.45 & 2.37 & 1.72 & 0.49 \\
\hline 34 & 22.74 & (-)-Aristolene & 0.05 & - & 0.07 & - & 0.07 & - \\
\hline 35 & 23.18 & Caryophyllene & 1.73 & 6.95 & 0.91 & 1.23 & 2.28 & 11.50 \\
\hline 36 & 23.51 & $\begin{array}{c}\text { 1,1,3a-trimethyl-7- } \\
\text { methylenedeca } \\
\text { Hydro- } \\
\text { 1H-cyclopropa[a] } \\
\text { naphthalene }\end{array}$ & - & - & - & - & - & 0.22 \\
\hline 37 & 23.76 & $\begin{array}{l}\text { Selina-3,7(11)- } \\
\text { diene }\end{array}$ & - & - & - & - & - & 0.22 \\
\hline 38 & 23.95 & Aromadendrene & 0.06 & 0.24 & - & 0.05 & 0.14 & 2.20 \\
\hline 39 & 24.30 & ç-gurjunene & - & - & - & - & - & 0.17 \\
\hline 40 & 24.69 & $\alpha$-humulene & 0.62 & 1.51 & 0.30 & 0.28 & 1.11 & 3.13 \\
\hline 41 & 24.84 & $\begin{array}{c}\alpha \text {-cyclo- } \\
\text { homogeraniol }\end{array}$ & 0.05 & 0.05 & 0.07 & - & 0.08 & - \\
\hline 42 & 25.52 & ç-muurolene & - & - & 0.05 & - & - & - \\
\hline 43 & 26.11 & Ledene & - & 0.09 & - & - & 0.05 & 0.75 \\
\hline 44 & 26.34 & Bicyclogermacrene & - & 0.18 & - & - & 0.04 & 0.75 \\
\hline 45 & 27.26 & ë-cadinene & - & - & 0.07 & 0.04 & - & 0.26 \\
\hline 46 & 29.66 & (-)-spathulenol & 0.06 & 0.14 & 0.06 & 0.06 & 0.11 & 0.56 \\
\hline 47 & 29.82 & $\begin{array}{l}\text { (-)-caryophyllene } \\
\text { oxide }\end{array}$ & 0.29 & 0.53 & 0.37 & 0.54 & 0.29 & 0.23 \\
\hline 48 & 30.32 & Veridiflorol & 0.28 & 1.20 & 0.30 & 0.22 & 0.60 & 2.33 \\
\hline 49 & 30.93 & Humulene oxide & 0.10 & 0.12 & 0.13 & 0.15 & 0.16 & 0.17 \\
\hline 50 & 32.00 & $\begin{array}{c}\text { Tetracyclo[6.3.2.0 } \\
(2,5) .0 \\
(1,8)] \text { tridecan-9- } \\
\text { ol, } \\
\text { 4,4-dimethyl- }\end{array}$ & - & - & - & 0.07 & - & - \\
\hline 51 & 32.71 & $\begin{array}{c}\text { (-)-caryophyllene } \\
\text { oxide }\end{array}$ & - & - & - & 0.08 & - & - \\
\hline 52 & 33.30 & $\begin{array}{l}\text { Isoaromadendrene } \\
\text { epoxide }\end{array}$ & & - & - & 0.06 & - & - \\
\hline 53 & 34.10 & 6-epi-shyobunol & - & - & - & - & - & 0.41 \\
\hline 54 & 46.04 & 13-epimanool & 0.04 & 0.17 & 0.12 & 0.05 & 0.21 & 0.29 \\
\hline
\end{tabular}

Egyptian J. Desert Res., 65, No. 2, 291-307 (2015) 


\section{CONCLUSION}

The best locations for cultivation and production of three-lobed sage as a promising land in the desert were El-Maghara location followed by ElQantara Sharq location and then Siwa Oasis location.

\section{REFERENCES}

Abd El-Azim, W.M. (2003). Production of Salvia officinalis L. plant under North Sinai conditions. Ph.D. Thesis, Fac. Agric., Cairo Univ., Egypt.

Abd El-Wahab, M.A. (2013). Productivity of marjoram (Origanum majoranum L.) in variable ecosystem locations in Egypt. Middle East Journal of Applied Sciences, 3 (3): 83-89.

Amedie, F.A. (2013). Impacts of climate change on plant growth, ecosystem services, biodeversity and potential adaptation measure. M.Sc. Thesis, University of Gothenburg.

Aziz, R.A., F. Hamed and N.A. Abdulah (2008). Determination of the main components of the essential oil extracted from Salvia fruticosa by using GC and GC-MS. Journal of Agricultural Sciences, Damascus University, 24 (2): 223-236.

British Pharmacopoeia (1963). In "Determination of Volatile Oil in Drugs". The Pharmaceutical Press, London.

Cvetkovikj, I., G. Stefkov, M. Karapandzova and S. Kulevanova (2015). Essential oil composition of Salvia fruticosa Mill. populations from Balkan Peninsula. Macedonian Pharmaceutical Bulletin, 61 (1): 1926.

European Medicines Agency (2015). Assessment report on Salvia fruticosa Mill., folium. 15 pp.

European Pharmacopoeia 5.0 (2005). Sage leaf, three-lobed. 01/2005:1561.

FAO (2015). Climate change and food systems: global assessments and implications for food security and trade. Rome.

Hückstädt, A.B., L.M. Mortensen and H.R. Gislerod (2013). The effect of high maximum day temperatures and coloured film cover on morphogenesis of some herbs in a $\mathrm{CO}_{2}$ enriched greenhouse atmosphere. Europ. J. Hort. Sci., 78 (5): 203-208.

International Trade Center (2015). Essential oils and oleoresins. Market Insider Report, September 2015, Geneve, Switzerland.

International Trade Center (2015). Medicinal plants and natural ingredients. Market Insider Report, December 2015, Geneve, Switzerland.

Karousou, R., D. Vokou and S. Kokkini (1998). Variation of Salvia fruticosa essential oils on the island of Crete (Greece). Bot. Acta, 111 (3): 250-254. 
Khan, MTH and A. Ather (2006). In "Lead Molecules from Natural Products". Volume 2, Elsevier, 448 pp.

Kintzios, S.E. (2003). In "Sage: The Genus Salvia". CRC Press, 289 pp.

Mastro, G., N. de-Aiello, F. Scartezzini, C. Vender and G. Brunetti (2006). Herbage yield and essential oil quality of three cultivars of sage (Salvia officinalis L.) grown in two Italian environments. Acta Hort., 723: 233-237.

Müller-Riebau, F.J., B.M. Berger, O. Yegen, C. Cakir (1997). Seasonal variations in the chemical compositions of essential oils of selected aromatic plants growing wild in Turkey. Journal of Agricultural and Food Chemistry, 45 (12): 4821-4825.

Putievsky, E., U. Ravid and Dudai N. (1986). The essential oil and yield components from various plant parts of Salvia fruticosa. Journal of Natural Products, 49 (6): 1015-1017.

Rivera, D., C. Obón and F. Cano (1994). The botany, history and traditional uses of three-lobed sage (Salvia fruticosa Miller) (Labiatae). Economic Botany, 48 (2): 190-195.

Roberts, E.H. and R.J. Summerfield (1987). In "Measurement and Prediction of Flowering in Annual Crops. (Atherton, J.G. Ed.). Manipulation of Flowering. Butterworths, London, p. 17-50.

Snedecor, G.W. and W.G. Cochran (1982). In "Statistical Methods". The Iowa State Univ. Press, Ames, Iowa, U.S.A., 507 pp.

UNDP, GEF and LARI (2013). Conservation Guideline for Medicinal and Aromatic Plants (MAPs) in Lebanon. Mainstreaming Biodiversity Management into Medicinal and Aromatic Plants (MAPs) Production Processes Project in Lebanon.

Yaniv, Z. and N. Dudai (2014). In "Medicinal and Aromatic Plants of the Middle-East". Springer, $337 \mathrm{pp}$.

Zawislak, G. (2006). Effect of weather conditions on growth, yield and biologically active compounds content in the sage (Salvia officinalis L.). Annales Universitatis Mariae Curie-Sklodowska. Sectio EEE, Horti., 16: 101-112. 


\section{تأثير مواقع الزراعة المختلفة فى مصر على نباتات المريمية ثلاثية الورقة

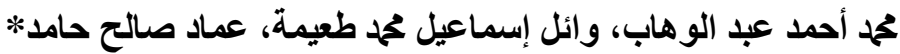

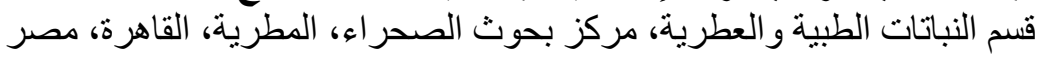

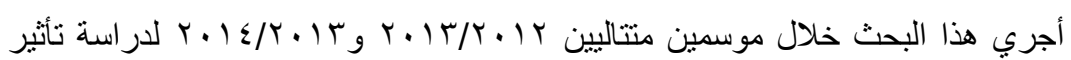

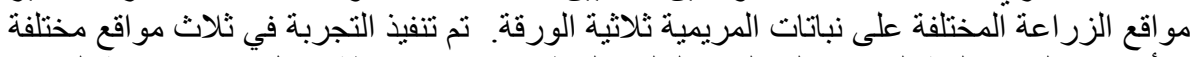

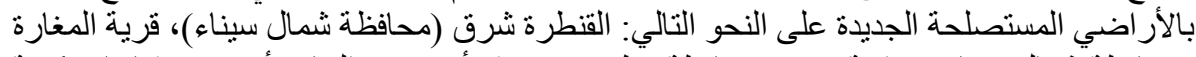

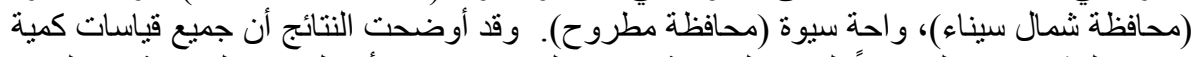

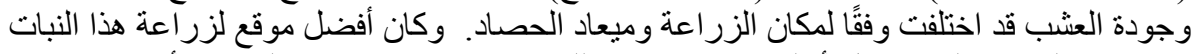

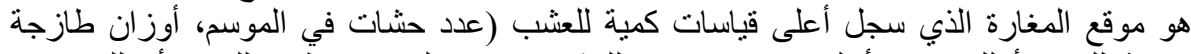



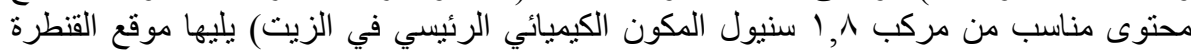
شرق ثم موقع واحة سيوة.

Egyptian J. Desert Res., 65, No. 2, 291-307 (2015) 